\title{
Rapid determination of plutonium isotopes in small samples using single anion exchange separation and ICP-MS/MS measurement in NH3-He mode for sediment dating
}

Xu, Yihong; Li, Chen; Yu, Haiping; Fang, Fengman; Hou, Xiaolin; Zhang, Chao; Li, Xiaofei; Xing, Shan

Published in:

Talanta

Link to article, DOI:

10.1016/j.talanta.2021.123152

Publication date:

2022

Document Version

Publisher's PDF, also known as Version of record

Link back to DTU Orbit

Citation $(A P A)$ :

Xu, Y., Li, C., Yu, H., Fang, F., Hou, X., Zhang, C., Li, X., \& Xing, S. (2022). Rapid determination of plutonium isotopes in small samples using single anion exchange separation and ICP-MS/MS measurement in $\mathrm{NH}_{3}-\mathrm{He}$ mode for sediment dating. Talanta, 240, [123152]. https://doi.org/10.1016/j.talanta.2021.123152

\section{General rights}

Copyright and moral rights for the publications made accessible in the public portal are retained by the authors and/or other copyright owners and it is a condition of accessing publications that users recognise and abide by the legal requirements associated with these rights.

- Users may download and print one copy of any publication from the public portal for the purpose of private study or research.

- You may not further distribute the material or use it for any profit-making activity or commercial gain

- You may freely distribute the URL identifying the publication in the public portal 


\title{
Rapid determination of plutonium isotopes in small samples using single anion exchange separation and ICP-MS/MS measurement in $\mathrm{NH}_{3}-\mathrm{He}$ mode for sediment dating
}

\author{
Yihong $\mathrm{Xu}^{\mathrm{a}}{ }^{\text {,* }}$, Chen $\mathrm{Li}^{\mathrm{a}}$, Haiping $\mathrm{Yu}^{\mathrm{a}}$, Fengman Fang ${ }^{\mathrm{a}}$, Xiaolin Hou ${ }^{\mathrm{b}, \mathrm{c}}$, Chao Zhang ${ }^{\mathrm{a}}$, \\ Xiaofei Li ${ }^{a}$, Shan Xing ${ }^{\text {d, } * *}$ \\ ${ }^{a}$ The Key Laboratory of Earth Surface Processes and Regional Response in the Yangtze Huaihe River Basin, School of Geography and Tourism, Anhui Normal University, \\ Wuhu, 241002, China \\ ${ }^{\mathrm{b}}$ Technical University of Denmark, Department of Environmental Engineering, Ris $\phi$ Campus, Roskilde, DK-4000, Denmark \\ c State Key Laboratory of Loess and Quaternary Geology, Shaanxi Key Laboratory of Accelerator Mass Spectrometry Technology and Application, Xi'an AMS Center, \\ Institute of Earth Environment, Chinese Academy of Sciences, Xi'an, 710061, China \\ d China Institute for Radiation Protection, Taiyuan, 030000, China
}

\section{A R T I C L E I N F O}

\section{Keywords:}

ICP-MS/MS

$\mathrm{NH}_{3}-\mathrm{He}$ mode

Elimination of uranium interference

Plutonium isotopes

Sediment dating

\begin{abstract}
A B S T R A C T
To accurately determine ultra-trace $\mathrm{Pu}$ isotopes in small environmental samples, we explored ICP-MS/MS in $\mathrm{NH}_{3}-\mathrm{He}$ mode, and investigated mechanism of ${ }^{238} \mathrm{U}$ interference removal and measurement sensitivity improvement for plutonium isotopes. The interference of uranium and uranium hydrides was effectively eliminated using $0.4 \mathrm{~mL} / \mathrm{min} \mathrm{NH}_{3}$ as reaction gas by shifting them to $\mathrm{U}\left(\mathrm{NH}_{\mathrm{m}}\right)_{\mathrm{n}}{ }^{+}$and $\mathrm{UH}\left(\mathrm{NH}_{\mathrm{m}}\right)_{\mathrm{n}}{ }^{+}$. The overall interference of uranium was reduced to $<2.4 \times 10^{-7}$, while remaining excellent ${ }^{239} \mathrm{Pu}$ sensitivity $(13,900 \mathrm{Mcps} /$ $(\mathrm{mg} / \mathrm{L})$ ) mainly due to ion focusing effect of Pu by helium gas. On this basis, the purification of plutonium using a single AG1 $\times 4$ column was proved to be sufficient for accurate determination of plutonium isotopes by the developed detection method, and the detection limits for the method were estimated to be $0.16 \mathrm{fg}(0.4 \mu \mathrm{Bq})$ for ${ }^{239} \mathrm{Pu}, 0.046 \mathrm{fg}(0.4 \mu \mathrm{Bq})$ for ${ }^{240} \mathrm{Pu}$ and $0.039 \mathrm{fg}(0.15 \mathrm{mBq})$ for ${ }^{241} \mathrm{Pu}$. The method was validated by analyzing plutonium isotopes in certificated reference materials and reported environmental samples of only 1-2 g. The analytical results of ultra-trace Pu isotopes in small amounts $(\sim 1 \mathrm{~g})$ of lake sediments obtained by the developed method were successfully applied to sediment dating.
\end{abstract}

\section{Introduction}

Since the 1940s, plutonium $(\mathrm{Pu})$ isotopes have been released into the environment by a series of human nuclear activities. ${ }^{239} \mathrm{Pu}\left(\mathrm{T}_{1 / 2}=\right.$ $24,100 \mathrm{y}),{ }^{240} \mathrm{Pu}\left(\mathrm{T}_{1 / 2}=6561 \mathrm{y}\right)$ and ${ }^{241} \mathrm{Pu}\left(\mathrm{T}_{1 / 2}=14.4 \mathrm{y}\right)$ have been not only the focus of the attention in the field of radioecology because of their high chemical toxicity and radiotoxicity [1,2], but also increasingly applied as powerful tracers for various environmental studies in recent years, such as ocean processes [3,4], lake deposition [5,6] and soil erosion [7-9]. More recently, plutonium isotopes were even suggested as a good primary marker for the Anthropocene by researchers $[10,11]$. Especially, the atomic ratios of ${ }^{240} \mathrm{Pu} /{ }^{239} \mathrm{Pu}$ and ${ }^{241} \mathrm{Pu} /{ }^{239} \mathrm{Pu}$ could serve as sensitive indicators for source identification of $\mathrm{Pu}$ contamination [12,13].

However, the sample amount used for the analysis of plutonium isotopes is very limited in the above-mentioned environmental studies, especially the high-resolution historical environmental reconstruction studies, because the samples in these studies are usually difficult to obtain, and each sample normally needs to be divided into several small portions for the analysis of multiple indicators. Given the ultra-trace levels of $\mathrm{Pu}$ isotopes in environmental samples, it is more challenging to accurately measure them in samples with small amount. Thus, it is of particular importance to develop a method for accurate determination of $\mathrm{Pu}$ isotopes in small environmental samples.

The inductively coupled plasma mass spectrometry (ICP-MS) has become the most powerful analytical tool for measuring Pu isotopes in

\footnotetext{
* Corresponding author.

$* *$ Corresponding author.

E-mail addresses: yhxu@ahnu.edu.cn (Y. Xu), xingshan.yc@foxmail.com (S. Xing).
} 
environmental samples, due to its easier accessible with relatively lower cost to AMS and TIMS, faster analysis, higher sensitivity and lower detection limits to the traditional alpha spectrometry, as well as the ability to obtain isotopic information [14,15]. However, for ICP-MS detection of $\mathrm{Pu}$ isotopes, the peak tailing of ${ }^{238} \mathrm{U}^{+}$and uranium hydrides ${ }^{238} \mathrm{U}^{1} \mathrm{H}^{+}$and $\left.{ }^{238} \mathrm{U}^{1} \mathrm{H}_{2}{ }^{+}\right)$were the major spectral interferences limiting the accurate determination of ${ }^{239} \mathrm{Pu}$ and ${ }^{240} \mathrm{Pu}$, especially for environmental samples with high $\mathrm{U}$ and low Pu concentrations [12]. Researchers have proposed a number of strategies to correct, minimize or eliminate U interferences for Pu measurement by ICP-MS, including using multistep chemical separation with different resins (e.g., AG1- $\times$ 4+TEVA [16], TEVE + UTEVA + DGA [17]) for removal of uranium and matrix constituents in samples [14], different types of mass spectrometers with high resolution and/or high sensitivity such as SF-ICP-MS and MC-ICP-MS, as well as different sample introduction systems such as desolvating systems (e.g. Apex-Q/ $/$ ). However, multistep chemical separation was very time consuming, while high-resolution mass spectrometers usually had drawbacks with higher purchase price, technical complexity and lower robustness [18]. Moreover, it is still difficult for the high-resolution instruments to resolve the uranium hydrides of ${ }^{238} \mathrm{UH}^{+}$and ${ }^{238} \mathrm{UH}_{2}{ }^{+}$from ${ }^{239} \mathrm{Pu}$ and ${ }^{240} \mathrm{Pu}$ peaks, especially for determination of ultra-trace level $\mathrm{Pu}$ in high $\mathrm{U}$ samples.

In addition to the above strategies, the collision-reaction cell (CRC) technology has widely been applied to ICP-MS (e.g., triple quadrupole ICP-MS) as a straightforward means $[15,18]$ to eliminate uranium interferences for measurement of plutonium isotopes. The CRC with the application of different collision/reaction gases (e.g., $\mathrm{NH}_{3}-\mathrm{He}, \mathrm{CO}_{2}, \mathrm{O}_{2}$ ) has shown its ability to effectively remove uranium interferences by more than 15 times compared to the conventional ICP-MS [15,19-21]. Although $\mathrm{O}_{2}$ and $\mathrm{CO}_{2}$ as reaction gases could effectively eliminate the interferences of uranium and its hydrides by converting to oxides of uranium ions, part of $\mathrm{Pu}$ could also react with these gases so that the intensity of the Pu signal was less than $3400 \mathrm{Mcps} /(\mathrm{mg} / \mathrm{L})$ even if the ICP-MS was equipped with a high-efficiency desolvation system (e. g, APEX-Q/ $\Omega$ ) [14]. In the $\mathrm{NH}_{3}-\mathrm{He}$ mode, compared with $\mathrm{O}_{2}$ and $\mathrm{CO}_{2}$, both high removal efficiency of interferences and remarkable intensity of $\mathrm{Pu}$ signal could be obtained simultaneously [21]. This made it possible to simultaneously determine ultra-low level ${ }^{239} \mathrm{Pu},{ }^{240} \mathrm{Pu}$ and ${ }^{241} \mathrm{Pu}$ in environmental samples even with small sample amount. However, due to the actual measuring upper limit of mass number in the older instrument (e.g., 260 amu for the Agilent 8800 ICP-MS/MS), the mechanism of the influence of $\mathrm{NH}_{3}$ on $\mathrm{U}$ interference elimination was still not very clear.

This work aimed to investigate the mechanism of $\mathrm{U}$ interference removal by reaction with $\mathrm{NH}_{3}$ and the $\mathrm{Pu}$ sensitivity improvement by collision with $\mathrm{He}$, in order to develop a highly sensitive analytical protocol for the determination of $\mathrm{Pu}$ isotopes $\left({ }^{239} \mathrm{Pu},{ }^{240} \mathrm{Pu}\right.$ and $\left.{ }^{241} \mathrm{Pu}\right)$ in small amount environmental samples $(<2 \mathrm{~g})$ by ICP-MS/MS equipped with a $\mathrm{CRC}$ in $\mathrm{NH}_{3}-\mathrm{He}$ mode. Meanwhile, the sample purification methods of both anion exchange chromatography and extraction chromatography was evaluated to establish a method for rapid determination of plutonium isotopes in small amount sediment samples for sediment dating.

\section{Materials and methods}

\subsection{Chemical reagents and samples}

All chemical reagents $\left(\mathrm{HNO}_{3}, \mathrm{HCl}, \mathrm{NaOH}, \mathrm{NH}_{3} \bullet \mathrm{H}_{2} \mathrm{O}, \mathrm{NaNO}_{2}\right.$, $\mathrm{FeCl}_{3} \bullet \mathrm{H}_{2} \mathrm{O}, \mathrm{K}_{2} \mathrm{~S}_{2} \mathrm{O}_{5}, \mathrm{NH}_{2} \mathrm{OH} \bullet \mathrm{HCl}$ ) used in this work were of analytical reagent grade without any further purification. ${ }^{242} \mathrm{Pu}$ (NIST-4334I) and ${ }^{238} \mathrm{U}$ (IRMM-183) were respectively purchased from the National Institute of Standards and Technology (NIST, Gaithersburg, MD, USA) and the Institute for Reference Materials and Measurements (IRRM, Belgium). AG1- $\times 4$ anion exchange resin (50-100 mesh, $\mathrm{Cl}^{-}$form, BioRad laboratories, California, USA) and TEVA resin (100-150 $\mu \mathrm{m}$,
TRISKEM International, Bruz, France) were used for separation of Pu. All working solutions used in this work were prepared using the deionized water (18.2 M $\Omega \bullet \mathrm{cm}$, Milli-Q reference water purification system, USA).

Two standard reference materials (IAEA-385 (Irish Sea sediment) and IAEA-327 (soil)) and two previously analyzed soil samples (Soil-1 and Soil-2) were used to validate the analytical method. Soil-1 and Soil-2 were obtained from the soil layers at $8-10 \mathrm{~cm}$ depth and $25-30 \mathrm{~cm}$ depth of our previously published DL-04 soil core, respectively [8]. Meanwhile, one sediment core collected from the Lake Ge (Fig. S1) in eastern China in 2019 was analyzed to verify the practicability of the method. The sediment core with $40 \mathrm{~cm}$ depth was sliced at $1 \mathrm{~cm}$ intervals.

\subsection{Instrumentation and setup}

The Agilent 8900 ICP-MS/MS (Agilent Technologies, USA) was used for the analysis of Pu isotopes. An APEX- $\Omega$ high efficiency sample introduction system (Elemental Scientific Inc, Omaha, NE, USA) with a spiro TMD heated membrane desolvation module and a PFA-100 nebulizer were used as sample introduction systems to enhance the instrument sensitivity. $\mathrm{NH}_{3}-\mathrm{He}\left(10 \% \mathrm{NH}_{3}-90 \% \mathrm{He}, 99.999 \%\right.$ purity $)$ and $\mathrm{He}$ (99.999\% purity) were introduced into the CRC via different inlets. The parameters of the ICP-MS/MS and the APEX- $\Omega$ were optimized before the measurement by using $0.2 \mu \mathrm{g} / \mathrm{L}$ of uranium solution and 0.1 $\mathrm{ng} / \mathrm{L}$ of ${ }^{242} \mathrm{Pu}$ standard solutions as shown in Table 1 . The abundance sensitivity of ${ }^{238} \mathrm{U}$ at $m / z=237$ was measured to be about $10^{-9}$ in no gas mode. The $0.1 \mathrm{ng} / \mathrm{mL}$ of $\mathrm{In}^{3+}\left(\mathrm{InCl}_{3}\right)$ and $0.5 \mathrm{~mol} / \mathrm{L} \mathrm{HNO}_{3}$ solutions were used as internal standard and washing solution for the measurement, respectively. No memory effects were observed in consecutive measurements of samples with different levels of uranium and plutonium.

In addition, the NexION 5000 ICP-MS (PerkinElmer, Waltham, USA) in combination with the Apex- $\Omega$ sample introduction system was used for measuring $\mathrm{Pu}$ isotopes in only $\mathrm{NH}_{3}$ mode and their optimized parameters were listed in Table S1.

Table 1

Instrument parameters and data acquisition settings for ICP-MS/MS measurement of $\mathrm{Pu}$ isotopes.

\begin{tabular}{|c|c|c|c|c|c|}
\hline \multirow[t]{8}{*}{$A P E X-\Omega$} & & \multicolumn{2}{|c|}{ Sample uptake rate } & & $0.2 \mathrm{~mL} / \mathrm{min}$ \\
\hline & & \multicolumn{2}{|c|}{ Nitrogen } & & $1.90 \mathrm{~mL} / \mathrm{min}$ \\
\hline & & \multicolumn{2}{|l|}{ Argon } & & $3.67 \mathrm{~mL} / \mathrm{min}$ \\
\hline & & \multicolumn{2}{|c|}{ Spray Chamber temperature } & & $140^{\circ} \mathrm{C}$ \\
\hline & & \multicolumn{2}{|c|}{ Peltier Cooler temperature } & & $3{ }^{\circ} \mathrm{C}$ \\
\hline & & \multicolumn{2}{|c|}{ Desolvator temperature } & & $155^{\circ} \mathrm{C}$ \\
\hline & & \multicolumn{2}{|c|}{ Peripump speed } & & $17 \mathrm{rpm}$ \\
\hline & & \multicolumn{2}{|c|}{ Peripump flow } & & $0.6 \mathrm{~mL} / \mathrm{min}$ \\
\hline \multirow{3}{*}{\multicolumn{2}{|c|}{ ICP conditions }} & \multicolumn{2}{|c|}{ RF power } & & $1590 \mathrm{~W}$ \\
\hline & & \multicolumn{2}{|c|}{ Sampling depth } & & $7.0 \mathrm{~mm}$ \\
\hline & & \multicolumn{2}{|l|}{ Carrier gas } & & $0.91 \mathrm{~L} / \mathrm{min}$ \\
\hline \multirow[t]{8}{*}{ Lens } & & \multicolumn{2}{|c|}{ Extraction lens 1} & & $2.2 \mathrm{~V}$ \\
\hline & & \multicolumn{2}{|c|}{ Extraction lens 2} & & $-220 \mathrm{~V}$ \\
\hline & & \multicolumn{2}{|c|}{ Omega bias } & & $-196 \mathrm{~V}$ \\
\hline & & Omega & & & $12.1 \mathrm{~V}$ \\
\hline & & Q1 entranc & & & $3.5 \mathrm{~V}$ \\
\hline & & Q1 outlet & & & $4.8 \mathrm{~V}$ \\
\hline & & Cell entran & & & $-148 \mathrm{~V}$ \\
\hline & & Cell outlet & & & $-112 \mathrm{~V}$ \\
\hline Q1 & & Q1 bias & & & $1.1 \mathrm{~V}$ \\
\hline Collision/reaction cell & & He flow & & & $6.4 \mathrm{~mL} / \mathrm{min}$ \\
\hline & & $\mathrm{NH}_{3}$ flow & & & $0.4 \mathrm{~mL} / \mathrm{min}$ \\
\hline & & Octapole b & & & $-5.5 \mathrm{~V}$ \\
\hline & & Octapole R & & & $179 \mathrm{~V}$ \\
\hline & & Axial accel & & & $1.6 \mathrm{~V}$ \\
\hline & & KED & & & $-11.2 \mathrm{~V}$ \\
\hline Data acquisition & & & & & \\
\hline Isotope & ${ }^{238} \mathrm{U}$ & ${ }^{239} \mathrm{Pu}$ & ${ }^{240} \mathrm{Pu}$ & ${ }^{241} \mathrm{Pu}$ & $\overline{{ }^{242} \mathrm{Pu}}$ \\
\hline Dwell time $1 / \mathrm{s}$ & 0.5 & 20 & 30 & 30 & 5 \\
\hline Scans & 100 & 100 & 100 & 100 & 100 \\
\hline Times & 4 & 4 & 4 & 4 & 4 \\
\hline
\end{tabular}




\subsection{Sample preparation}

In order to recommend a chemical procedure to meet the requirements of accurate and rapid analysis of plutonium isotopes, anion exchange chromatography, extraction chromatography, and their combination were tested for their performance in the separation and purification of $\mathrm{Pu}$ in environmental solid samples after acid leaching and coprecipitation. A flow chart of the three chemical procedures is shown in Fig. 1 and their detailed descriptions have been reported elsewhere [14, 20]. Briefly, after being ashed, a known amount soil or sediment sample $(1-2 \mathrm{~g})$ was spiked with a known amount of ${ }^{242} \mathrm{Pu}(\sim 2 \mathrm{pg})$ as chemical yield tracer and then leached with aqua regia. After being co-precipitated with iron hydroxides, dissolved with concentrated $\mathrm{HCl}$, and converted to $\mathrm{Pu}$ (IV), $\mathrm{Pu}$ isotopes were separated and purified by using the AG1- $\times 4$ anion exchange column (1 cm in diameter and $12 \mathrm{~cm}$ in length) and TEVA column $(0.7 \mathrm{~cm}$ in diameter and $5 \mathrm{~cm}$ in length) and the combination of the above two columns. The separated plutonium in eluate was heated to near dryness and dissolved in $2 \mathrm{~mL} 0.5 \mathrm{~mol} / \mathrm{L} \mathrm{HNO}_{3}$ for the measurement of $\mathrm{Pu}$ isotopes by ICP-MS/MS. Chemical yield of $\mathrm{Pu}$ in all analyzed samples ranged from $70 \%$ to $90 \%$.

\section{Results and discussion}

\subsection{Comparison of the removal efficiency of $U$ interference at different $\mathrm{NH}_{3}$ flow rates}

In general, the ${ }^{238} \mathrm{U}^{+}$peak tailing and its polyatomic ions $\left({ }^{238} \mathrm{UH}^{+}\right.$ and ${ }^{238} \mathrm{UH}_{2}{ }^{+}$) are the major interferences for the accurate measurement of ${ }^{239} \mathrm{Pu}$ and ${ }^{240} \mathrm{Pu}$ by ICP-MS, while other potential interferents generated in the plasma from atmospheric and matrix components (e.g., $\mathrm{O}, \mathrm{S}, \mathrm{Cl}, \mathrm{Ar}, \mathrm{Hg}, \mathrm{Pb}, \mathrm{Tl}, \mathrm{Bi}$ ) are very minor or ignorable (see the measurement results of the interferences of polyatomic ions of $50 \mu \mathrm{g} / \mathrm{L}$ $\mathrm{Pb}$ and $\mathrm{Tl}$ in the $0.5 \mathrm{~mol} / \mathrm{mL} \mathrm{HNO}_{3}$ and $0.5 \mathrm{~mol} / \mathrm{mL} \mathrm{HNO}_{3}-0.1 \mathrm{~mol} / \mathrm{mL}$ $\mathrm{HCl}$ to the measurement of ${ }^{239},{ }^{240} \mathrm{Pu}$ with Apex- $\Omega$-ICP-MS/MS using different collision-reaction mode in Table S2). To investigate the potential new species formed in the CRC filled with $\mathrm{NH}_{3}$ as reaction gas, ${ }^{238} \mathrm{U}$ standard solution was injected to the ICP-MS/MS. The first quadrupole mass filter (Q1) was set at $\mathrm{m} / \mathrm{z}$ of 238 and 239 for ${ }^{238} \mathrm{U}^{+}$and ${ }^{238} \mathrm{UH}^{+}$, respectively, and the reaction product ions with $\mathrm{m} / \mathrm{z}$ of 238-275 were scanned in the second quadrupole mass filter (Q2) and measured in the detector. The measured intensities of those potential ions (counts/s) and their relative proportions were shown in Table S3 and Table S4. It can be seen that the dominant new species of uranium formed in the CRC were $\mathrm{U}\left(\mathrm{NH}_{\mathrm{m}}\right)_{\mathrm{n}}{ }^{+}$and $\mathrm{UH}\left(\mathrm{NH}_{\mathrm{m}}\right)_{\mathrm{n}}{ }^{+}(\mathrm{m}, \mathrm{n}=1-2)$, the proportions of which showed no significant discrepancy at different $\mathrm{NH}_{3}$ flow rates $\left(87.1 \%, 89.9 \%\right.$ and $87.9 \%$ for $\mathrm{NH}_{3}$ at flow rates of $0.4 \mathrm{~mL} /$ $\mathrm{min}, 0.24 \mathrm{~mL} / \mathrm{min}$ and $0.09 \mathrm{~mL} / \mathrm{min}$, respectively). With the increase of $\mathrm{NH}_{3}$ flow rate, the proportion of $\mathrm{U}^{+}$ions decreased from $11.5 \%$ to $6.7 \%$, while the proportion of $\mathrm{UH}^{+}$ions did not change obviously, indicating that part of $\mathrm{U}^{+}$ions generated other uranium species (e.g., $\mathrm{UN}^{+}, \mathrm{UHN}_{2}{ }^{+}$ and $\left.\mathrm{U}\left(\mathrm{NH}_{3}\right)_{2}{ }^{+}\right)$at the higher $\mathrm{NH}_{3}$ flow rate. The measured intensity at the $m / z$ of 238 was only $8100 \mathrm{cps} /(\mu \mathrm{g} / \mathrm{L}$ uranium) at a flow rate of 0.4 $\mathrm{mL} / \mathrm{min}$ for $\mathrm{NH}_{3}$. Since it was impossible to discriminate and measure the contributions of uranium and uranium hydride to the $m / z=239$ and the obtained tailing contribution of uranium to $m / z=237\left(10^{-9}\right)$ were generally higher than that to $m / z=239$, it was reasonable to infer that the peak tailing effect of ${ }^{238} \mathrm{U}$ to $m / z 239$ was completely negligible.

Table $S 4$ showed that the main product ions formed in the reaction of $\mathrm{UH}^{+}$with $\mathrm{NH}_{3}$ at a flow rate of $0.4 \mathrm{~mL} / \mathrm{min}$ were $\mathrm{U}(\mathrm{NH})^{+}(17.1 \%), \mathrm{U}$ $\left(\mathrm{NH}_{2}\right)^{+}(33.0 \%)$ and $\mathrm{HU}(\mathrm{NH})_{2}{ }^{+}(13.2 \%)$, followed by $\mathrm{UN}^{+}(8.5 \%), \mathrm{U}$ $\left(\mathrm{NH}_{2}\right)_{2}{ }^{+}(5.8 \%)$ and $\mathrm{HU}\left(\mathrm{NH}_{2}\right)_{2}{ }^{+}(5.1 \%)$, other species, such as $\mathrm{U}\left(\mathrm{NH}_{3}\right)_{2}{ }^{+}$ $(2.6 \%)$ and $\mathrm{HU}\left(\mathrm{NH}_{3}\right)_{2}{ }^{+}(<0.01 \%)$ were minor. Furthermore, it was

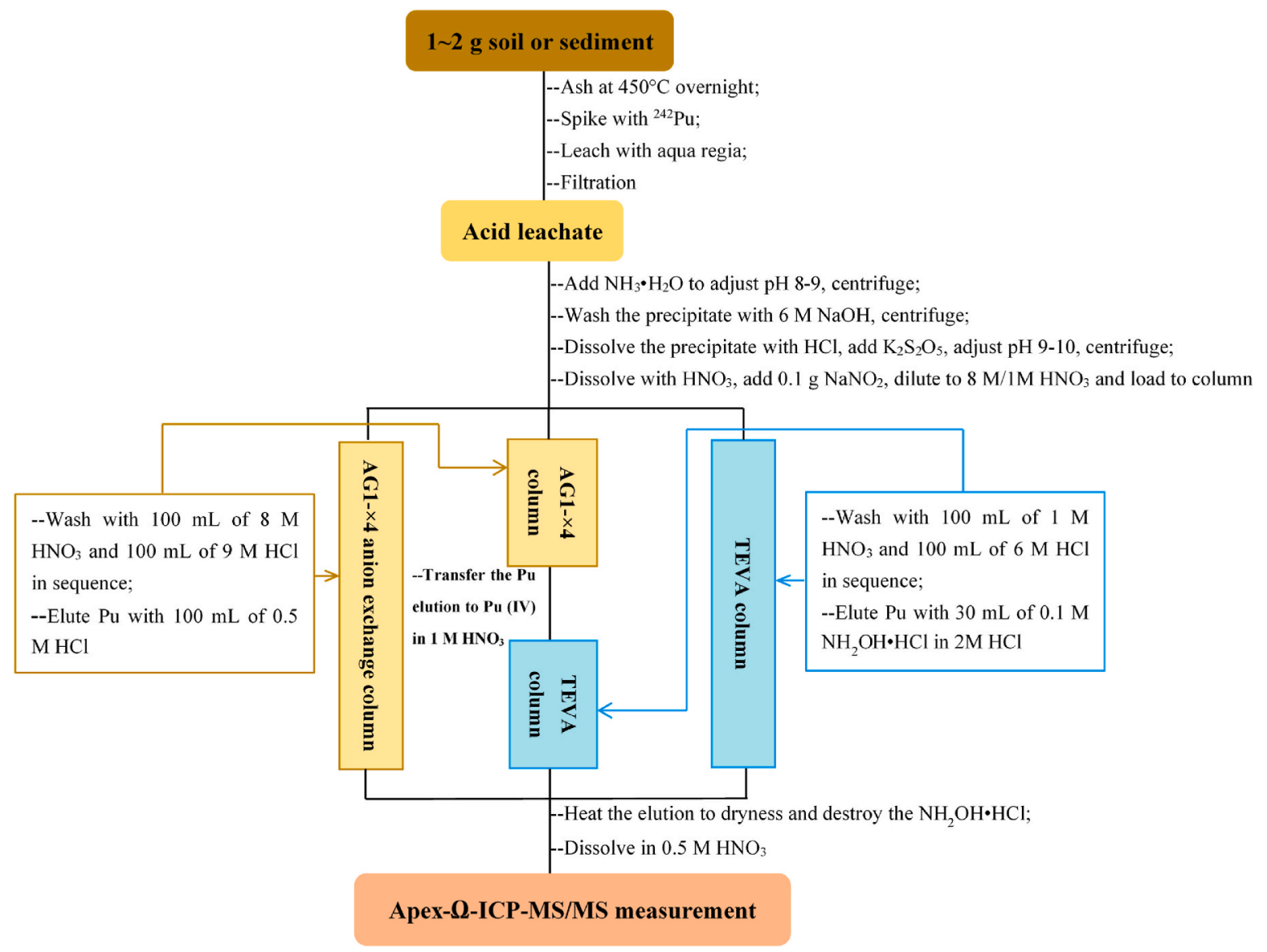

Fig. 1. The flow chart of the analytical procedures of Pu isotopes for the ICP-MS/MS measurement. 
observed that $\mathrm{U}^{+}$and $\mathrm{UH}^{+}$accounted for $4.2 \%$ and $6.1 \%$, respectively. The contribution of the remaining $\mathrm{UH}^{+}$ions to the intensity of the $\mathrm{m} / \mathrm{z}$ 239 was about $3.3 \mathrm{cps} /(\mu \mathrm{g} / \mathrm{L}$ uranium $)$. It was found that there was a little discrepancy between the sensitivity of Pu $(24,000 \mathrm{Mcps} /(\mathrm{mg} / \mathrm{L}))$ and $\mathrm{U}(22,000 \mathrm{Mcps} /(\mathrm{mg} / \mathrm{L}))$ at $9 \mathrm{~mL} / \mathrm{min}$ He. Thus, monitoring the signal intensity of $\mathrm{Pu}$ at $0.4 \mathrm{~mL} / \mathrm{min} \mathrm{NH}_{3}(13,900 \mathrm{Mcps} /(\mathrm{mg} / \mathrm{L}))$ could approximately represent the "real" sensitivity of $\mathrm{U}^{+}$to estimate the removal efficiency of $\mathrm{UH}^{+}$ions. The $\mathrm{UH}^{+} / \mathrm{U}^{+}$ratio was therefore calculated to be $2.4 \times 10^{-7}$, which was $1-2$ orders of magnitude lower than those of ICP-MS/MS in $\mathrm{NH}_{3}-\mathrm{He}$, He and $\mathrm{O}_{2}$ mode and two orders of magnitude lower than those of MC-ICP-MS and SF-ICP-MS [22-24] (Table S5). These results suggested that the developed detection method was enabled to measure ${ }^{239} \mathrm{Pu}$ in samples containing about $10^{7}$ times higher uranium.

As shown in Table S6, when ${ }^{242} \mathrm{Pu}$ standard solution was injected to the ICP-MS and the $m / z$ of 242 was selected in Q1, the formed species in the CRC filled with $\mathrm{NH}_{3}$ at a flow rate of $0.4 \mathrm{~mL} / \mathrm{min}$ was dominated by ${ }^{242} \mathrm{Pu}^{+}$(accounting for $94.7 \%$ of all $\mathrm{Pu}$ species) with an intensity of $13,900 \mathrm{Mcps} /(\mathrm{mg} / \mathrm{L})$. The formed species of $\mathrm{Pu}(\mathrm{NH})^{+}$and $\mathrm{Pu}\left(\mathrm{NH}_{3}\right)^{+}$ only accounted for about $1.6 \%$ and $1.9 \%$. It was observed that the intensities of ${ }^{242} \mathrm{Pu}^{+}$were only reduced by a factor of $85 \%$, from 16,200 $\mathrm{Mcps} /(\mathrm{mg} / \mathrm{L})$ ) at $0.09 \mathrm{~mL} / \mathrm{min} \mathrm{NH}_{3}-7.11 \mathrm{~mL} / \mathrm{min}$ He to $13,900 \mathrm{Mcps} /$ $(\mathrm{mg} / \mathrm{L}))$ at $0.4 \mathrm{~mL} / \mathrm{min} \mathrm{NH}_{3}-6.4 \mathrm{~mL} / \mathrm{min}$ He. While the measured intensity of ${ }^{238} \mathrm{U}^{+}$decreased by a factor of 115 when the $\mathrm{NH}_{3}$ flow rate increased from $0.09 \mathrm{~mL} / \mathrm{min}$ to $0.40 \mathrm{~mL} / \mathrm{min}$. Similarly, the measured intensity of ${ }^{238} \mathrm{UH}^{+}$was reduced by a factor of about 100 to only $3.3 \mathrm{cps} /$ $1.0 \mathrm{mg} / \mathrm{L}$ uranium at $0.4 \mathrm{~mL} / \mathrm{min} \mathrm{NH} 3-6.4 \mathrm{~mL} / \mathrm{min}$ He compared to only $9 \mathrm{~mL} / \mathrm{min}$ helium as collision/reaction gas. In consideration of interferences removal and the sensitivity of $\mathrm{Pu}^{+}$ions, $0.4 \mathrm{~mL} / \mathrm{min} \mathrm{NH} \mathrm{N}_{3}-6.4$ $\mathrm{mL} / \mathrm{min} \mathrm{He}$ was selected as optimal collision/reaction gas condition for the determination of plutonium isotopes. Moreover, interestingly, from the proportions of species formed in the reactions of $\mathrm{U}^{+}, \mathrm{UH}^{+}$and $\mathrm{Pu}^{+}$ with $\mathrm{NH}_{3}$, it could also be observed that if $\mathrm{Pu}\left(\mathrm{NH}_{3}\right)^{+}$was selected as the analyte ion in the mass-shift mode, the $\mathrm{U}\left(\mathrm{NH}_{3}\right)^{+}$tailing and $\mathrm{U}\left(\mathrm{NH}_{4}\right)^{+}$ were considered as the major interferences. In this case, the contributions of $\mathrm{U}\left(\mathrm{NH}_{3}\right)^{+}$and $\mathrm{U}\left(\mathrm{NH}_{4}\right)^{+}$to the intensity of the $\mathrm{m} / z 259$ were only $0.004 \mathrm{cps} /(\mu \mathrm{g} / \mathrm{L})$ and $0 \mathrm{cps} /(\mu \mathrm{g} / \mathrm{L})$, respectively, which were nearly 3 orders of magnitude lower than those of $\mathrm{U}^{+}$and $\mathrm{UH}^{+}$to the intensity of the $m / z 239$ in the on-mass mode. It meant that the interference of uranium on $\mathrm{Pu}$ isotopes measurement in the mass-shift mode (by measuring ${ }^{239} \mathrm{Pu}\left(\mathrm{NH}_{3}\right)^{+}, \quad{ }^{240} \mathrm{Pu}\left(\mathrm{NH}_{3}\right)^{+}$and $\left.{ }^{241} \mathrm{Pu}\left(\mathrm{NH}_{3}\right)^{+}\right)$was completely negligible. However, since the sensitivity of $\mathrm{Pu}\left(\mathrm{NH}_{3}\right)^{+}$was

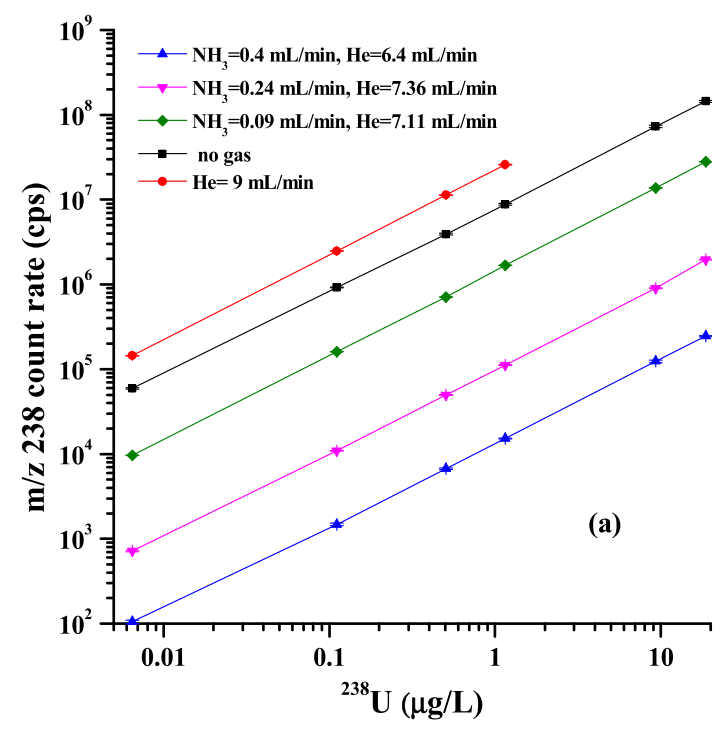

also only $273 \mathrm{Mcps} /(\mathrm{mg} / \mathrm{L})$, the detection limit of ${ }^{239} \mathrm{Pu}$ could not be improved by using the mass-shift mode, and therefore might only be suitable for the analysis of samples with both high uranium and high plutonium levels.

In order to further understand the influence of ${ }^{238} \mathrm{U}$ on the accurate determination of ${ }^{239} \mathrm{Pu}$, the contributions of ${ }^{238} \mathrm{U}$ with different concentrations to the intensities of the $\mathrm{m} / \mathrm{z}$ of 239 different flow rates of $\mathrm{NH}_{3}-\mathrm{He}$ were investigated as illustrated in Fig. 2. Fig. 2a showed that the signal intensities of the $m / z 238$ measured without $\mathrm{NH}_{3}$ as reaction gas (no gas mode and He mode) were much higher than those in the $\mathrm{NH}_{3}$-He mode, further revealing that the $\mathrm{NH}_{3}$ could significantly suppress the signal intensity of ${ }^{238} \mathrm{U}$ by shifting $\mathrm{U}^{+}$to polyatomic ions $(\mathrm{U}$ $\left(\mathrm{NH}_{\mathrm{m}}\right)_{\mathrm{n}}{ }^{+}$. Moreover, when the flow rate of $\mathrm{NH}_{3}$ was $0.4 \mathrm{~mL} / \mathrm{min}$, the signal intensity of ${ }^{238} \mathrm{U}^{+}$was suppressed by at least 2 to 3 orders of magnitude compared with the mode without $\mathrm{NH}_{3}$ as reaction gas, which was at least one order of magnitude higher than reported by Xing et al. [19]. Fig. 2b showed that when the concentration of ${ }^{238} \mathrm{U}$ was less than $0.1 \mu \mathrm{g} / \mathrm{L}$, the contribution of ${ }^{238} \mathrm{U}$ to the signal intensity of the $\mathrm{m} / \mathrm{z} 239$ was less than 0.3 cps (Fig. 2b) due to the significantly reduced ${ }^{238} \mathrm{U}^{+}$ signal and therefore very small tailing to the $m / z=239$. This further confirmed that the major interference to the $m / z 239$ came from the contribution of ${ }^{238} \mathrm{UH}^{+}$.

\subsection{Effect of the collision mechanism on the sensitivity of plutonium}

The measured sensitivity of $\mathrm{Pu}^{+}$ion in helium gas mode using ICPMS/MS with Apex- $\Omega$ introduction system was up to 24,000 Mcps/ (mg/L), and that in $\mathrm{NH}_{3}-\mathrm{He}$ mode ranged from $13,900 \mathrm{Mcps} /(\mathrm{mg} / \mathrm{L})$ to $16,200 \mathrm{Mcps} /(\mathrm{mg} / \mathrm{L})$, which was 1.7-2.9 times higher than that in nogas mode $(8120 \mathrm{Mcps} /(\mathrm{mg} / \mathrm{L}))$. Similar results were also observed in the ICP-MS/MS measurements of uranium isotopes, with 5 times higher sensitivity of uranium isotopes in He mode (750 Mcps (mg/L)) than that in no-gas mode (150 Mcps/(mg/L)) [14]. All these results were attributed to the application of collision gases. Furthermore, some key instrumental parameters (e.g., the axial acceleration voltage and the kinetic energy discrimination (KED) voltage) were investigated for their influence on the intensity of plutonium signal.

When ${ }^{242} \mathrm{Pu}$ standard solution was injected and the mass 242 was selected in Q1 and ions with $m / z 242$ to 275 were selected in Q2 and measured in the detector, the variation of ${ }^{242} \mathrm{Pu}$ sensitivity measured at different axial acceleration voltages, $\mathrm{NH}_{3}$-and $\mathrm{He}$ flow rates and $\mathrm{KED}$ voltages was shown in Fig. 3. The axial acceleration voltage was first

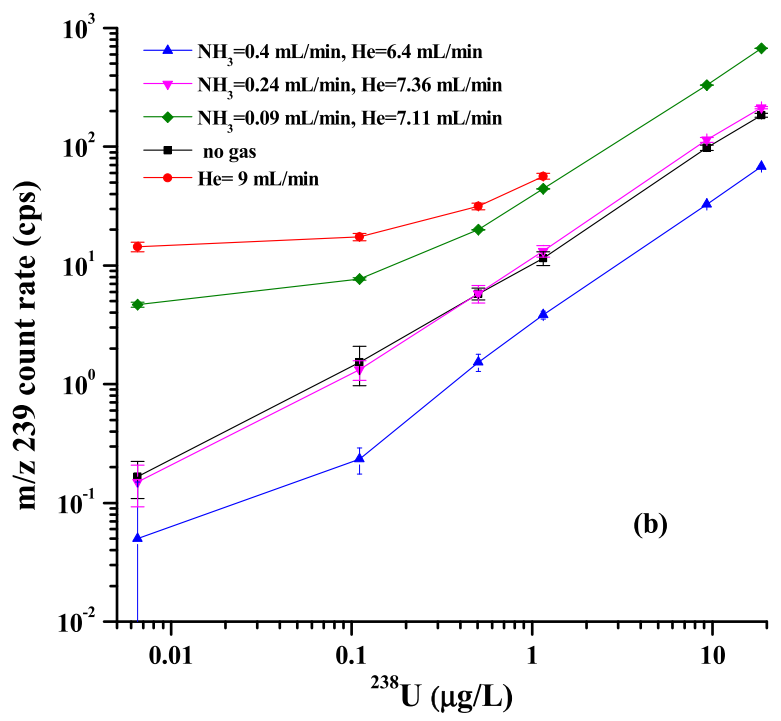

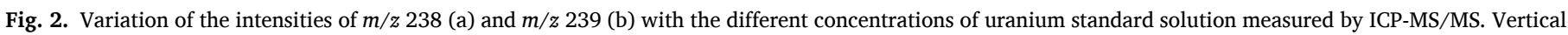
error bars correspond to \pm 1 standard deviation. 

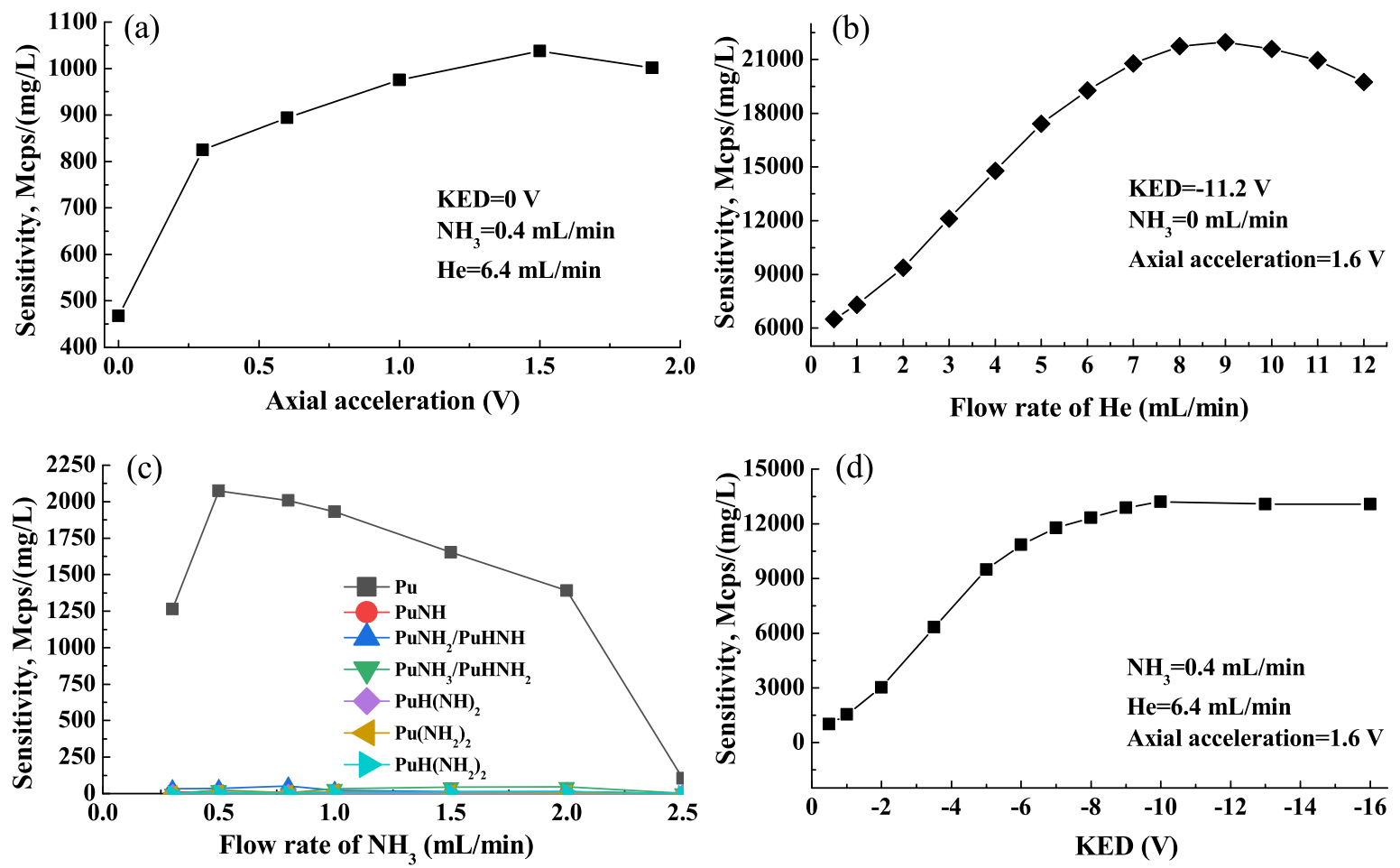

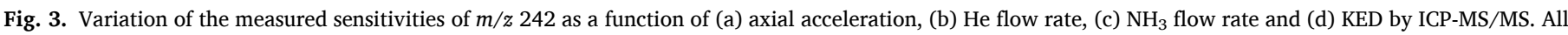

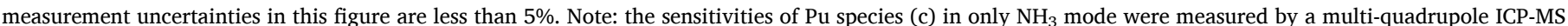
(NexION 5000 ICP-MS, PerkinElmer, Waltham, USA).

applied along the $\mathrm{X}$-axis of the $\mathrm{CRC}$ to produce a potential gradient. As shown in Fig. 3a, when the axial acceleration voltage increased from $0 \mathrm{~V}$ to $1.5 \mathrm{~V}$ at $0 \mathrm{~V} \mathrm{KED}$ and $0.4 \mathrm{~mL} / \mathrm{min} \mathrm{NH}_{3}-6.4 \mathrm{~mL} / \mathrm{min}$ He flow rate, the sensitivity of plutonium increased from $470 \mathrm{Mcps} /(\mathrm{mg} / \mathrm{L})$ to 1040 $\mathrm{Mcps} /(\mathrm{mg} / \mathrm{L})$, and decreased slightly when KED was increased to $2.0 \mathrm{~V}$ (1000 Mcps/(mg/L)). This was mainly because the axial acceleration voltage could induce the energy loss through the collision between ions and gases, reducing the scattering loss of ions, and then enhancing ion focusing and improving ions to enter to Q2. Meanwhile, excessive axial acceleration voltage might weaken the ion focusing effect of gas on the ion beam thus led to the slight decrease of Pu sensitivity. Fig. 3b showed that $\mathrm{Pu}^{+}$sensitivity increased obviously with the increase of $\mathrm{He}$ flow rate under He mode. When the flow rate of He increased from $0.5 \mathrm{~mL} / \mathrm{min}$ to $9 \mathrm{~mL} / \mathrm{min}$, the $\mathrm{Pu}^{+}$sensitivity increased from $6490 \mathrm{Mcps} /(\mathrm{mg} / \mathrm{L})$ to $22,000 \mathrm{Mcps} /(\mathrm{mg} / \mathrm{L})$, and then the sensitivity decreased slightly to $19,800 \mathrm{Mcps} /(\mathrm{mg} / \mathrm{L})$ with further increase of He flow rate. This could be attributed to the loss of kinetic energy of $\mathrm{Pu}^{+}$ions by elastic collision with $\mathrm{He}$ atoms. It has been observed that the kinetic energy of the heavy mass ions decreased from $20 \mathrm{eV}$ to $<8 \mathrm{eV},<4 \mathrm{eV}$ and $<2 \mathrm{eV}$ when the flow rate of He was $0 \mathrm{~mL} / \mathrm{min}, 5 \mathrm{~mL} / \mathrm{min}$ and $10 \mathrm{~mL} / \mathrm{min}$, respectively. The lower the ion energy after collision, the stronger the ion signal intensity [25]. It was indicated that due to the narrow entrance and exit of the octopole collision/reaction cell, the helium gas as a collision gas could avoid the loss caused by the inelastic collision between the ions and the octupole, and provide a better focusing effect, which helped the transmission of the analyte ions through the CRC to enter the Q2. Unlike the influence of $\mathrm{He}$ on the $\mathrm{Pu}$ sensitivity, when pure $\mathrm{NH}_{3}$ was injected to the CRC, the Pu sensitivity increased first and then decreased with the increase of $\mathrm{NH}_{3}$ flow rate, and the highest $\mathrm{Pu}$ sensitivity was 2070 Mcps/(mg/L) at the $\mathrm{NH}_{3}$ flow rate of $0.5 \mathrm{~mL} / \mathrm{min}$ (Fig. 3c). Since the Agilent 8900 ICP-MS/MS did not support the application of pure $\mathrm{NH}_{3}$, here we used a new type of multi-quadrupole ICP-MS (NexION 5000 ICP-MS, PerkinElmer, Waltham, USA) for the investigation of influence of $\mathrm{NH}_{3}$ on the Pu sensitivity. It was observed that when $\mathrm{NH}_{3}$ was at low flow rate, $\mathrm{Pu}$ almost did not react with $\mathrm{NH}_{3}\left(>95 \%\right.$, Table S6), and $\mathrm{NH}_{3}$ had a similar focusing effect on Pu ions as He. It was well known that the lighter molecular mass of gas was, the less the scattering loss of the ions when the elastic collision was occurred. Therefore, with the increase of $\mathrm{NH}_{3}$ flow rate, $\mathrm{Pu}$ ions suffered a greater scattering loss by collision with the relatively heavy molecular $\mathrm{NH}_{3}$, resulting in the decrease of $\mathrm{Pu}$ sensitivity.

$\mathrm{Pu}^{+}$ion sensitivity was only $1020 \mathrm{Mcps} /(\mathrm{mg} / \mathrm{L})$ in $\mathrm{NH}_{3}-\mathrm{He}$ mode when the KED voltage was $-0.5 \mathrm{~V}$ (Fig. 3d), and increased by about 13 times $(13,200 \mathrm{Mcps} /(\mathrm{mg} / \mathrm{L}))$ when the KED voltage decreased to $-10 \mathrm{~V}$. As the voltage continued to decrease to $-16 \mathrm{~V}, \mathrm{Pu}^{+}$sensitivity decreased slightly to $13,100 \mathrm{Mcps} /(\mathrm{mg} / \mathrm{L})$. The KED voltage was set between the exit of the CRC and Q2. The positive voltage was mainly used for separating the target ions and the polyatomic ions with obvious energy difference, and the negative voltage was mainly used to provide energy for the ions with large energy loss after the collision/reaction so that they could enter Q2. It has been demonstrated in the above discussion that $\mathrm{U}^{+}$and $\mathrm{UH}^{+}$interferences to $\mathrm{Pu}$ could be effectively eliminated in the $\mathrm{NH}_{3}-\mathrm{He}$ mode at the flow rate of $0.4 \mathrm{~mL} / \mathrm{min} \mathrm{NH}_{3}-6.4 \mathrm{~mL} / \mathrm{min} \mathrm{He}$, and setting negative KED voltage could significantly improve the $\mathrm{Pu}^{+}$ sensitivity. The KED voltage was observed to have a larger improvement on $\mathrm{Pu}^{+}$sensitivity (13 times) than that of the axial acceleration voltage (2.2 times) (Fig. 3a and 3d). This was mainly because heavy ions suffer more loss of their initial energy in the CRC, and the ion energy compensation by the KED voltage $(-11.2 \mathrm{~V})$ was obviously higher than that by the maximum axial acceleration voltage $(1.6 \mathrm{~V})$.

Based on the above results, the KED voltage, axial acceleration voltage and the flow rate of $\mathrm{NH}_{3}-\mathrm{He}$ in the developed method for the measurement of $\mathrm{Pu}$ isotopes were set as $-11.2 \mathrm{~V}, 1.6 \mathrm{~V}$ and $0.4 \mathrm{~mL} / \mathrm{min}$ $\mathrm{NH}_{3}-6.4 \mathrm{~mL} / \mathrm{min} \mathrm{He}$, respectively.

3.3. Performance evaluation for determining Pu isotopes in reference materials and environmental samples treated by different chemical separations

Although U interference could be effectively eliminated by ICP-MS/ 
MS in the $\mathrm{NH}_{3}-\mathrm{He}$ mode, chemical procedures still needed to be carried out to pre-concentrate and separate plutonium from sample matrix prior to the measurement. In this work, we compared the performances of the AG1- $\times 4$ anion exchange chromatography and TEVA extraction chromatography as well as their combination for separation and purification of $\mathrm{Pu}$ using the developed ICP-MS/MS detection method. Table 2 showed the results of ${ }^{238} \mathrm{U},{ }^{239} \mathrm{Pu},{ }^{240} \mathrm{Pu}$ and ${ }^{241} \mathrm{Pu}$ count rates in background and procedure blanks treated by different chemical separations. The instrument blank was obtained by determining the $0.5 \mathrm{~mol} / \mathrm{L} \mathrm{HNO}_{3}$ solution and the results showed that the measured ${ }^{238} \mathrm{U}$ and ${ }^{239} \mathrm{Pu}$ were $2.23 \mathrm{cps}$ and $0.06 \mathrm{cps}$, respectively, which were at least $1-2$ orders of magnitude lower than those in all procedure blanks and environmental samples.

While for the procedure blanks, it was worth noting that no matter what separation techniques were applied, the count rates of ${ }^{239} \mathrm{Pu},{ }^{240} \mathrm{Pu}$ and ${ }^{241} \mathrm{Pu}$ in all procedure blanks were in little varied ranges of $0.35-0.80 \mathrm{cps}, 0.06-0.12 \mathrm{cps}$ and $0.04-0.13 \mathrm{cps}$, respectively. These results were attributed to the effective suppression of $U$ signals by the developed ICP-MS/MS method. Even though the ${ }^{238} \mathrm{U}$ counts rates in the procedure blanks treated by a single AG1 $-\times 4$ anion exchange resin column were generally one order of magnitude higher than those in the other two kind procedure blanks, their contribution to the ${ }^{239} \mathrm{Pu}$ signal was insignificant with less than $1 \mathrm{cps}$. All these results indicated that the purification of plutonium using a single AG1- $\times 4$ column should be sufficient for accurate determination of plutonium by the developed detection method, which could be further verified by the results obtained from the certificated reference materials and environmental samples as discussed below. Based on the measured results of the procedure blanks $(n=4)$ treated by a single AG1 $-\times 4$ column with the chemical yield of plutonium (average 85\%) in the entire separation procedure, the detection limit of the method $\left(\mathrm{L}_{\mathrm{d}}\right)$ could be estimated using the Currie equation [26]:

$L_{d}=2 \times k \times \sigma_{0}$

Where $\mathrm{k}=1.645$ for a $90 \%$ confidence level; $\sigma_{0}$ is the standard deviation of the procedure blanks measurement (fg), which was calculated to be $0.05 \mathrm{fg}$ for ${ }^{239} \mathrm{Pu}, 0.014 \mathrm{fg}$ for ${ }^{240} \mathrm{Pu}$ and $0.012 \mathrm{fg}$ for ${ }^{241} \mathrm{Pu}$ in this work. Therefore, on the basis of analyzing $1 \mathrm{~g}$ of soil or sediment, the detection limits for the developed method were estimated to be $0.16 \mathrm{fg}(0.4 \mu \mathrm{Bq})$ for ${ }^{239} \mathrm{Pu}, 0.046 \mathrm{fg}(0.4 \mu \mathrm{Bq})$ for ${ }^{240} \mathrm{Pu}$ and $0.039 \mathrm{fg}(0.15 \mathrm{mBq})$ for ${ }^{241} \mathrm{Pu}$, which were generally lower than those reported with $\mathrm{CO}_{2}-\mathrm{He}$ as the reaction gas in the CRC using ICP-MS/MS (Agilent 8800, 0.2 fg for ${ }^{239} \mathrm{Pu}$ and $0.1 \mathrm{fg}$ for ${ }^{240} \mathrm{Pu}$ ) [14] and even better than those obtained by the Apex-SF-ICP-MS $\left(0.24\right.$ fg for ${ }^{239} \mathrm{Pu}, 0.14 \mathrm{fg}$ for ${ }^{240} \mathrm{Pu}$ and $0.09 \mathrm{fg}$ for ${ }^{241} \mathrm{Pu}$ ) [17].

To further validate the present method, two reference materials (IAEA-385 and IAEA-327) and two reported environmental soil samples (soil-1 and soil-2) were prepared with different chemical separation procedures and analyzed for ${ }^{239} \mathrm{Pu},{ }^{240} \mathrm{Pu}$ and ${ }^{241} \mathrm{Pu}$ by the developed ICP-MS/MS method. The measured ${ }^{238} \mathrm{U}$ count rates and Pu isotopes concentrations in the final separated solutions of the IAEA-383 and
IAEA-327 and two soil samples of 1-2 g were shown in Table 3. The results showed that although the measured ${ }^{238} \mathrm{U}$ count rates in sample solution separated using single AG1- $\times 4$ anion exchange resin column (5470 cps for IAEA-385 and 6870 cps for IAEA-327) were nearly 1 order of magnitude higher than those using the TEVA column and the combination of the AG1 $-\times 4$ anion exchange and TEVA columns $(<1100 \mathrm{cps}$ for IAEA-385 and $<390 \mathrm{cps}$ for IAEA-327), the contributions of ${ }^{238} \mathrm{U}$ to ${ }^{239} \mathrm{Pu}$ signals for the single AG1 $-\times 4$ column separation procedure were $<1 \mathrm{cps}$, which was at least two orders of magnitude lower than that the count rates at $m / z=239$ in the prepared samples. There were no significant discrepancies among the analytical results of ${ }^{240} \mathrm{Pu} /{ }^{239} \mathrm{Pu}$ atomic ratios $(0.9 \%$ for IAEA-385 and $1.6 \%$ for IAEA-327) and concentrations of ${ }^{239} \mathrm{Pu}$ (1.3\% for IAEA-385 and $7.5 \%$ for IAEA-327), ${ }^{240} \mathrm{Pu}$ (1.2\% for IAEA-383 and $9.6 \%$ for IAEA-327) and ${ }^{241} \mathrm{Pu}(4.1 \%$ for IAEA385 and $11.3 \%$ for IAEA-327) for the two reference materials treated with the different chemical procedures, and all the measured values for the IAEA-385 and IAEA-327 agreed well with their certificated values [27] and literature reported values [21,28,29]. These results indicated that the one stage separation procedure using the anion-exchange chromatography combined with the developed ICP-MS/MS detection method should be reliable for the accurate measurement of low-level plutonium isotopes in environmental samples with small sample amount $(<2 \mathrm{~g})$. The analytical results of plutonium isotopes in the two environmental soil samples (soil-1 and soil-2) treated with single AG1$\times 4$ anion exchange chromatography (two replicates) further confirmed this conclusion. As shown in Table 3 , the ${ }^{239} \mathrm{Pu}$ and ${ }^{240} \mathrm{Pu}$ concentrations and their atomic ratios in soil-1 and soil-2 measured in this work using the sample amount of $\sim 1.5 \mathrm{~g}$ agreed very well with our previous results [8] obtained by a traditional ICP-MS (with Pu sensitivity of about 230 $\mathrm{Mcps} /(\mathrm{mg} / \mathrm{L})$ ) with the combination of anion exchange and TEVA chromatography using the sample amount of $\sim 10 \mathrm{~g}$. In addition, ${ }^{241} \mathrm{Pu}$ concentrations were also measured for the two soil samples with a discrepancy of $<15 \%$ between the two replicates. All these suggested that the one stage chemical procedure using the anion-exchange chromatography combined with the developed ICP-MS/MS detection method could be well applied for accurate and rapid determination of ultra-trace $\mathrm{Pu}$ isotopes in environmental samples with small sample amount.

\subsection{Application to the determination of Pu isotopes for sediment dating}

One sediment core collected from central China (Fig. S1) was analyzed using the developed method for Pu isotopes with the sample amount of $\sim 1 \mathrm{~g}$. The results were shown in Table S7 and Fig. 4. It should be specially noted that each layer sample of the sediment core was firstly determined for ${ }^{137} \mathrm{Cs}$ by gamma spectrometry to get a rough idea of the level of radionuclides in the samples, and the results showed that ${ }^{137} \mathrm{Cs}$ was generally undetectable in all layer samples of the lake sediment core using the sample amount of $>20 \mathrm{~g}$.

The ${ }^{239+240} \mathrm{Pu}\left({ }^{239} \mathrm{Pu}+{ }^{240} \mathrm{Pu}\right)$ activities in the sediment core were generally in a low range of $0.003 \pm 0.000 \mathrm{mBq} / \mathrm{g}$ to $0.147 \pm 0.007 \mathrm{mBq} /$

Table 2

Analytical results for ${ }^{238} \mathrm{U},{ }^{239} \mathrm{Pu},{ }^{240} \mathrm{Pu}$ and ${ }^{241} \mathrm{Pu}$ in background and procedure blanks.

\begin{tabular}{|c|c|c|c|c|c|c|c|}
\hline Sample & ${ }^{238} \mathrm{U}(\mathrm{cps})^{\mathrm{a}}$ & ${ }^{239} \mathrm{Pu}(\mathrm{cps})^{\mathrm{a}}$ & ${ }^{240} \mathrm{Pu}(\mathrm{cps})^{\mathrm{a}}$ & ${ }^{241} \mathrm{Pu}(\mathrm{cps})^{\mathrm{a}}$ & ${ }^{239} \mathrm{Pu}(\mathrm{fg})^{\mathrm{a}}$ & ${ }^{240} \mathrm{Pu}(\mathrm{fg})^{\mathrm{a}}$ & ${ }^{241} \mathrm{Pu}(\mathrm{fg})^{\mathrm{a}}$ \\
\hline Instrument Background & $2.23 \pm 1.72$ & $0.06 \pm 0.04$ & $0.04 \pm 0.03$ & $0.03 \pm 0.03$ & & & \\
\hline Procedure Blank-Anion exchange-1 & $1377 \pm 92$ & $0.75 \pm 0.18$ & $0.10 \pm 0.05$ & $0.07 \pm 0.02$ & $0.29 \pm 0.07$ & $0.039 \pm 0.021$ & $0.027 \pm 0.008$ \\
\hline Procedure Blank-Anion exchange-2 & $1496 \pm 54$ & $0.80 \pm 0.29$ & $0.06 \pm 0.06$ & $0.13 \pm 0.02$ & $0.25 \pm 0.09$ & $0.019 \pm 0.019$ & $0.042 \pm 0.008$ \\
\hline Procedure Blank-Anion exchange-3 & $1189 \pm 42$ & $0.60 \pm 0.18$ & ND & $0.04 \pm 0.03$ & $0.17 \pm 0.05$ & ND & $0.012 \pm 0.010$ \\
\hline Procedure Blank-Anion exchange- 4 & $1362 \pm 118$ & $0.62 \pm 0.30$ & $0.08 \pm 0.03$ & $0.09 \pm 0.05$ & $0.21 \pm 0.10$ & $0.045 \pm 0.019$ & $0.031 \pm 0.017$ \\
\hline Standard deviation of procedure blanks & & & & & 0.05 & 0.014 & 0.012 \\
\hline Detection limit & & & & & 0.16 & 0.046 & 0.039 \\
\hline Procedure Blank-TEVA & $260 \pm 38$ & $0.35 \pm 0.13$ & $0.07 \pm 0.06$ & ND & & & \\
\hline Procedure Blank- Anion exchange + TEVA & $230 \pm 64$ & $0.70 \pm 0.18$ & $0.12 \pm 0.10$ & $0.1 \pm 0.07$ & & & \\
\hline
\end{tabular}

${ }^{\text {a }}$ Uncertainties represent $1 \sigma$ error. ND, undetected. 
Table 3

Analytical results of ${ }^{238} \mathrm{U}, \mathrm{Pu}$ isotopes count rate and concentrations of Pu isotopes in environmental soil samples and IAEA reference samples.

\begin{tabular}{|c|c|c|c|c|c|c|c|c|}
\hline Sample & $\begin{array}{l}\text { Chemical } \\
\text { separation }\end{array}$ & $\begin{array}{l}\text { Sample } \\
\text { amount (g) }\end{array}$ & ${ }^{238} \mathrm{U}(\mathrm{cps})^{\mathrm{a}}$ & $\begin{array}{l}{ }^{240} \mathrm{Pu} /{ }^{239} \mathrm{Pu} \\
\text { atom ratio }\end{array}$ & $\begin{array}{l}{ }^{239} \mathrm{Pu} \text { activity } \\
\text { concentration }(\mathrm{mBq} / \mathrm{g})^{\mathrm{a}}\end{array}$ & $\begin{array}{l}{ }^{240} \mathrm{Pu} \text { activity } \\
\text { concentration }(\mathrm{mBq} / \mathrm{g})^{\mathrm{a}}\end{array}$ & $\begin{array}{l}{ }^{241} \mathrm{Pu} \text { activity } \\
\text { concentration }(\mathrm{mBq} / \\
\mathrm{g})^{\mathrm{a}, \mathrm{b}}\end{array}$ & References \\
\hline IAEA- & Anion exchange & 2.05 & $5470 \pm 50$ & $0.175 \pm 0.005$ & $1.95 \pm 0.05$ & $1.25 \pm 0.04$ & $11.33 \pm 0.30$ & This study \\
\hline \multirow[t]{3}{*}{385} & $\begin{array}{l}\text { TEVA } \\
\text { extraction }\end{array}$ & 2.05 & $1080 \pm 90$ & $0.173 \pm 0.005$ & $2.00 \pm 0.05$ & $1.26 \pm 0.03$ & $10.50 \pm 0.93$ & This study \\
\hline & $\begin{array}{l}\text { Anion } \\
\text { exchange }+ \\
\text { TEVA }\end{array}$ & 2.03 & $770 \pm 90$ & $0.176 \pm 0.003$ & $1.98 \pm 0.03$ & $1.28 \pm 0.02$ & $10.62 \pm 0.20$ & This study \\
\hline & \multicolumn{3}{|c|}{ Certificated or information values } & $0.174 \pm 0.032$ & $1.3-2.07$ & $0.97-1.32$ & $9.1 \pm 0.6$ & {$[27]$} \\
\hline IAEA- & Anion exchange & 1.52 & $6870 \pm 420$ & $0.180 \pm 0.007$ & $0.36 \pm 0.01$ & $0.24 \pm 0.01$ & $0.55 \pm 0.07$ & This study \\
\hline \multirow[t]{3}{*}{327} & $\begin{array}{l}\text { TEVA } \\
\text { extraction }\end{array}$ & 1.51 & $390 \pm 30$ & $0.175 \pm 0.013$ & $0.33 \pm 0.02$ & $0.21 \pm 0.02$ & $0.44 \pm 0.17$ & This study \\
\hline & $\begin{array}{l}\text { Anion } \\
\text { exchange }+ \\
\text { TEVA }\end{array}$ & 1.54 & $240 \pm 20$ & $0.18 \pm 0.02$ & $0.31 \pm 0.03$ & $0.20 \pm 0.02$ & $0.52 \pm 0.15$ & This study \\
\hline & \multicolumn{3}{|c|}{ Certificated or information values } & $0.19 \pm 0.02^{\mathrm{c}}$ & $0.35 \pm 0.02^{c}$ & $0.25 \pm 0.02^{c}$ & $0.63 \pm 0.20^{\mathrm{d}}$ & {$[28,29]$} \\
\hline \multirow[t]{3}{*}{ Soil-1 } & $\begin{array}{l}\text { Anion } \\
\text { exchange-1 }\end{array}$ & 1.52 & $2990 \pm 50$ & $0.187 \pm 0.006$ & $0.348 \pm 0.010$ & $0.239 \pm 0.009$ & $0.59 \pm 0.14$ & This study \\
\hline & $\begin{array}{l}\text { Anion } \\
\text { exchange-2 }\end{array}$ & 1.52 & $3430 \pm 300$ & $0.185 \pm 0.006$ & $0.354 \pm 0.006$ & $0.241 \pm 0.008$ & $0.48 \pm 0.09$ & This study \\
\hline & $\begin{array}{l}\text { Anion } \\
\text { exchange }+ \\
\text { TEVA }\end{array}$ & 9.76 & $\begin{array}{l}26,500 \pm \\
50\end{array}$ & $0.182 \pm 0.009$ & $0.350 \pm 0.009$ & $0.233 \pm 0.010$ & - & [8] \\
\hline \multirow[t]{3}{*}{ Soil-2 } & $\begin{array}{l}\text { Anion } \\
\text { exchange-1 }\end{array}$ & 1.51 & $1910 \pm 100$ & $0.176 \pm 0.010$ & $0.118 \pm 0.002$ & $0.076 \pm 0.004$ & $0.21 \pm 0.01$ & This study \\
\hline & $\begin{array}{l}\text { Anion } \\
\text { exchange-2 }\end{array}$ & 1.52 & $1410 \pm 90$ & $0.187 \pm 0.011$ & $0.112 \pm 0.004$ & $0.077 \pm 0.004$ & $0.25 \pm 0.01$ & This study \\
\hline & $\begin{array}{l}\text { Anion } \\
\text { exchange }+ \\
\text { TEVA }\end{array}$ & 9.83 & $\begin{array}{l}115,100 \pm \\
1700\end{array}$ & $0.179 \pm 0.015$ & $0.116 \pm 0.004$ & $0.076 \pm 0.006$ & - & [8] \\
\hline
\end{tabular}

a Uncertainties represent $1 \sigma$ error.

b Decay of ${ }^{241} \mathrm{Pu}$ was corrected to 1 st January 2021.

c Data cited from Röllin et al. [28].

d Data cited from Hrnecek et al. [29].
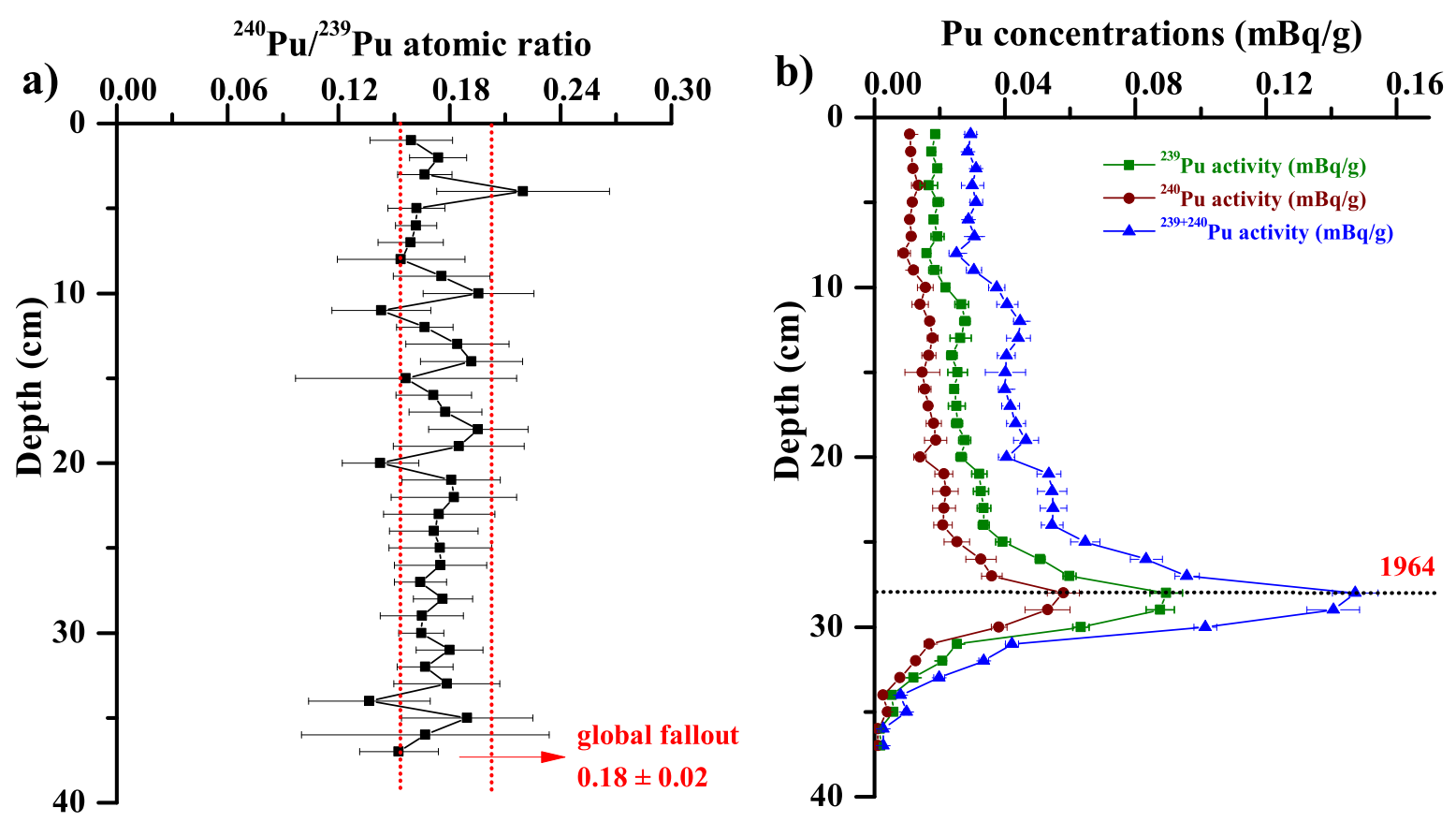

\section{GH-sediment core}

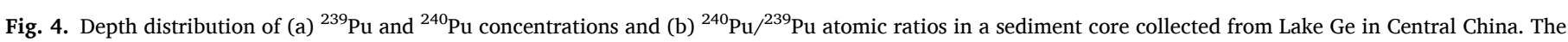

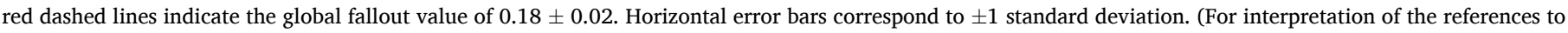
colour in this figure legend, the reader is referred to the Web version of this article.) 
g. These values were at least one order of magnitude lower than those (from $0.012 \pm 0.012 \mathrm{mBq} / \mathrm{g}$ to $1.698 \pm 0.210 \mathrm{mBq} / \mathrm{g}$ ) obtained in the sediments from the Lake Yangcheng [30], which is $<100 \mathrm{~km}$ far from the Lake Ge. However, the ${ }^{240} \mathrm{Pu} /{ }^{239} \mathrm{Pu}$ atomic ratios in the sediment core of the Lake Ge ranging from $0.137 \pm 0.033$ to $0.220 \pm 0.047$ with an average of $0.171 \pm 0.016$, generally fell in the range of the global fallout values [31] and also agreed well with the results (the ${ }^{240} \mathrm{Pu} /{ }^{239} \mathrm{Pu}$ atomic ratios with an average of 0.174 ) measured in the Lake Yangcheng [30]. This indicated that $\mathrm{Pu}$ in the Lake Ge should also be mainly from the global fallout. As for the reason for the large difference in Pu levels between the two close lakes, it might be attributed to their differences in the physical and chemical characteristics of sediments (affecting the adsorption of $\mathrm{Pu}$ isotopes) and geographical environment around the lakes [6], such as inflow rivers (riverine input $\mathrm{Pu}$ ).

Despite the ultra-low levels of $\mathrm{Pu}$ in the sediment core, the depth distribution of $\mathrm{Pu}$ isotopes showed an obvious maximum peak at the layer of $27-28 \mathrm{~cm}$ depth and decreased upwards and downwards from the peak (Fig. 4b). This distribution well recorded the sedimentation history in the lake. According to the principle of Pu isotopes as a time mark for sediment dating, the position of the maximum activities of $\mathrm{Pu}$ isotopes in the sediment core could be marked as the year of 1964 with the consideration of the time lag of ca. 1 year for global fallout radionuclides deposition from lake water to bottom sediments, given the fact that the main source of $\mathrm{Pu}$ isotopes in the Lake Ge was the global atmospheric fallout from the nuclear weapon tests peaked in 1963. The mean sedimentation rate at the sampling site in the Lake Ge was thus estimated to be $0.50 \mathrm{~cm} / \mathrm{y}$, which was comparable to that $(0.40 \pm 0.02$ $\mathrm{cm} / \mathrm{y}$, the maximum layer was corresponded to the year of 1963) in the Lake Yangcheng [30]. ${ }^{137} \mathrm{Cs}$ was well known as a traditional and wide applied dating method because of its easy determination by gamma spectrometry without chemical separation. However, due to its short half-life of 30.2 years, the ${ }^{137} \mathrm{Cs}$ dating method would be less and less applicable. Our results demonstrated that $\mathrm{Pu}$ isotopes could be an ideal substitute of ${ }^{137} \mathrm{Cs}$ for sediment dating due to the developed method for accurate analysis of $\mathrm{Pu}$ isotopes in small samples.

\section{Conclusions}

A sensitive and rapid method has been developed for the determination of ${ }^{239} \mathrm{Pu},{ }^{240} \mathrm{Pu}$ and ${ }^{241} \mathrm{Pu}$ in small environmental samples $(<2 \mathrm{~g})$ by using ICP-MS/MS in $\mathrm{NH}_{3}-\mathrm{He}$ mode combined with an APEX- $\Omega$ highefficiency sample introduction system. Both excellent $U$ interference removal ability $\left(2.4 \times 10^{-7}\right.$ for $\left.\mathrm{UH}^{+} / \mathrm{U}^{+}\right)$and high $\mathrm{Pu}^{+}$sensitivity $(13,900 \mathrm{Mcps} /(\mathrm{mg} / \mathrm{L}))$ were achieved at a flow rate of $0.4 \mathrm{~mL} / \mathrm{min} \mathrm{NH} \mathrm{N}^{-}$ $6.4 \mathrm{~mL} / \mathrm{min} \mathrm{He}$. In this mode, a simple one stage chemical separation method using a single AG1- $\times 4$ column was suitable for accurate determination of plutonium in ultra-low level samples, with the detection limits of $0.16 \mathrm{fg}(0.4 \mu \mathrm{Bq})$ for ${ }^{239} \mathrm{Pu}, 0.046 \mathrm{fg}(0.4 \mu \mathrm{Bq})$ for ${ }^{240} \mathrm{Pu}$ and $0.039 \mathrm{fg}(0.15 \mathrm{mBq})$ for ${ }^{241} \mathrm{Pu}$. The developed method was successfully applied to determine ultra-trace $\mathrm{Pu}$ isotopes in sediment samples with small amount of $\sim 1 \mathrm{~g}$ for sediment dating.

\section{Credit author statement}

The manuscript was written through contributions of all authors. Yihong Xu and Shan Xing designed the experiment, drafted, and revised the manuscript; Chen Li, Haiping Yu, Chao Zhang and Xiaofei Li implemented the experiment; Haiping Yu made the map; Yihong Xu was responsible for the measurement of Pu; Xiaolin Hou and Fengman Fang provided useful discussion and also revised the manuscript. All authors have given approval to the final version of the manuscript.

\section{Declaration of competing interest}

The authors declare that they have no known competing financial interests or personal relationships that could have appeared to influence the work reported in this paper.

\section{Acknowledgements}

Financial supports from the National Natural Science Foundation of China (No. 41877449 and 12175201), the doctoral startup fund of Anhui Normal University, the 2020 National Innovation and Entrepreneurship Training Program for college students (No. 202001372082), the Scientific Research Program for Young Talents of the China National Nuclear Corporation, as well as Environmental Radioactivity Network Center (ERAN) I-21-19 are gratefully acknowledged.

\section{Appendix A. Supplementary data}

Supplementary data to this article can be found online at https://doi. org/10.1016/j.talanta.2021.123152.

\section{References}

[1] J.A. Corcho Alvarado, F. Chawla, P. Froidevaux, Determining ${ }^{241} \mathrm{Pu}$ in environmental samples: case studies in alpine soils, Radiochim. Acta 99 (2011) 121-129, https://doi.org/10.1524/ract.2011.1803.

[2] D.I. Strumińska-Parulska, Vertical distribution of ${ }^{241} \mathrm{Pu}$ in the southern Baltic Sea sediments, Mar. Pollut. Bull. 89 (2014) 12-15.

[3] P. Lindahl, S.H. Lee, P. Worsfold, M. Keith-Roach, Plutonium isotopes as tracers for ocean processes: a review, Mar. Environ. Res. 69 (2010) 73-84.

[4] Y.H. Xu, S.M. Pan, J.H. Gao, X.L. Hou, Y.F. Ma, Y.P. Hao, Sedimentary record of plutonium in the North Yellow Sea and the response to catchment environmental changes of inflow rivers, Chemosphere 207 (2018) 130-138, https://doi.org/ 10.1016/j.chemosphere.2018.05.082.

[5] L.M. Sanders, K.H. Taffs, D. Stokes, A. Enrich-Prast, C.J. Sanders, ${ }^{239+240} \mathrm{Pu}$ depositional signatures as a viable geochronogical tool in the Amazon basin, Geochronometria 44 (2017) 142-149.

[6] H.T. Guo, Y.H. Xu, S.M. Pan, Z.Y. Liu, Distinctive distribution of global fallout plutonium isotopes in an alpine lake and its implications for sediment dating, Chemosphere 279 (2021) 130535, https://doi.org/10.1016/j. chemosphere.2021.130535.

[7] Y.H. Xu, J.X. Qiao, X.L. Hou, S.M. Pan, Plutonium in soils from northeast China and its potential application for evaluation of soil erosion, Sci. Rep. 3 (2013), https:// doi.org/10.1038/srep03506.

[8] Y.H. Xu, J.X. Qiao, S.M. Pan, X.L. Hou, P. Roos, L.G. Cao, Plutonium as a tracer for soil erosion assessment in northeast China, Sci. Total Environ. 511 (2015) $176-185$.

[9] W. Zhang, S. Xing, X. Hou, Evaluation of soil erosion and ecological rehabilitation in Loess Plateau region in Northwest China using plutonium isotopes, Soil Till. Res. 191 (2019) 162-170.

[10] T. Wang, L. Tan, H. Xu, J. Zang, D. Li, J. Lan, Y. Han, L. Li, The selection of a primary marker for the Anthropocene, Sci. Bull. 64 (2019) 1643-1645.

[11] J.-A. Sanchez-Cabeza, S.D. Rico-Esenaro, J.A. Corcho-Alvarado, S. Röllin, J. P. Carricart-Ganivet, P. Montagna, A.C. Ruiz-Fernández, A. Cearreta, Plutonium in coral archives: a good primary marker for an Anthropocene, Sci. Total Environ. 771 (2021) 145077.

[12] W. Bu, J. Zheng, Q. Guo, T. Aono, H. Tazoe, K. Tagami, S. Uchida, M. Yamada, A method of measurement of ${ }^{239} \mathrm{Pu},{ }^{240} \mathrm{Pu},{ }^{241} \mathrm{Pu}$ in high $\mathrm{U}$ content marine sediments by sector field ICP-MS and its application to Fukushima sediment samples, Environ. Sci. Technol. 48 (2014) 534-541.

[13] D.I. Strumińska-Parulska, Vertical distribution of ${ }^{241} \mathrm{Pu}$ in the southern Baltic Sea sediments, Mar. Pollut. Bull. 89 (2014) 12-15.

[14] X. Hou, W. Zhang, Y. Wang, Determination of femtogram-level plutonium isotopes in environmental and forensic samples with high-level Uranium using chemical separation and ICP-MS/MS measurement, Anal. Chem. 91 (2019) 11553-11561.

[15] S. Diez-Fernández, H. Isnard, A. Nonell, C. Bresson, F. Chartier, Radionuclide analysis using collision-reaction cell ICP-MS technology: a review, J. Anal. At. Spectrom. 35 (2020) 2793-2819.

[16] Y. Xu, J. Qiao, X. Hou, S. Pan, P. Roos, Determination of plutonium isotopes $\left({ }^{238} \mathrm{Pu}\right.$, ${ }^{239} \mathrm{Pu},{ }^{240} \mathrm{Pu},{ }^{241} \mathrm{Pu}$ ) in environmental samples using radiochemical separation combined with radiometric and mass spectrometric measurements, Talanta 119 (2014) 590-595.

[17] Z. Wang, J. Zheng, Y. Ni, W. Men, K. Tagami, S. Uchida, High-performance method for determination of Pu Isotopes in soil and sediment samples by sector fieldinductively coupled plasma mass spectrometry, Anal. Chem. 89 (2017) 2221-2226.

[18] L. Balcaen, E. Bolea-Fernandez, M. Resano, F. Vanhaecke, Inductively coupled plasma-Tandem mass spectrometry (ICP-MS/MS): a powerful and universal tool for the interference-free determination of (ultra)trace elements - a tutorial review, Anal. Chim. Acta 894 (2015) 7-19.

[19] S. Xing, W. Zhang, J. Qiao, X. Hou, Detemination of ultra-low level plutonium isotopes $\left({ }^{239} \mathrm{Pu},{ }^{240} \mathrm{Pu}\right)$ in environmental samples with high uranium, Talanta 187 (2018) 357-364.

[20] W. Zhang, J. Lin, S. Fang, C. Li, X. Yi, X. Hou, N. Chen, H. Zhang, Y. Xu, H. Dang, W. Wang, J. Xu, Determination of ultra-trace level plutonium isotopes in soil 
samples by triple-quadrupole inductively coupled plasma-mass spectrometry with mass-shift mode combined with UTEVA chromatographic separation, Talanta 234 (2021) 122652, https://doi.org/10.1016/j.talanta.2021.122652.

[21] W. Bu, M. Gu, X. Ding, Y. Ni, X. Shao, X. Liu, C. Yang, S. Hu, Exploring the ability of triple quadrupole inductively coupled plasma mass spectrometry for the determination of $\mathrm{Pu}$ isotopes in environmental samples, J. Anal. At. Spectrom. (2021), https://doi.org/10.1039/D1JA00288K.

[22] P. Lindahl, M. Keith-Roach, P. Worsfold, M.S. Choi, H.S. Shin, S.H. Lee, Ultra-trace determination of plutonium in marine samples using multi-collector inductively coupled plasma mass spectrometry, Anal. Chim. Acta 671 (2020) (2010) 61-69, https://doi.org/10.1016/j.aca.2010.05.012.

[23] J. Zheng, M. Yamada, Inductively coupled plasma-sector field mass spectrometry with a high-efficiency sample introduction system for the determination of $\mathrm{Pu}$ isotopes in settling particles at femtogram levels, Talanta 69 (2006) 1246-1253, https://doi.org/10.1016/j.talanta.2005.12.047.

[24] J. Zheng, Evaluation of a new sector-field ICP-MS with Jet Interface for ultra-trace determination of Pu isotopes: from femtogram to attogram levels, J. Nucl. Radiochem. Sci. 15 (2015) 7-13, https://doi.org/10.14494/jnrs.15.1_7.

[25] S.F. Boulyga, J.S. Becker, Improvement of abundance sensitivity in a quadrupolebased ICP-MS instrument with a hexapole collision cell, J. Anal. At. Spectrom. 17 (2002) 1202-1206, https://doi.org/10.1039/b203086c.

[26] L.A. Currie, Detection and quantification limits: origins and historical overview, Anal. Chim. Acta 391 (1999) 127-134, https://doi.org/10.1016/S0003-2670(99) 00105-1.
[27] M.K. Pham, J.A. Sanchez-Cabeza, P.P. Povinec, K. Andor, D. Arnold, M. Benmansour, I. Bikit, F.P. Carvalho, K. Dimitrova, Z.H. Edrev, C. Engeler, F. J. Fouche, J. Garcia-Orellana, C. Gascó, J. Gastaud, A. Gudelis, G. Hancock, E. Holm, F. Legarda, T.K. Ikäheimonen, C. Ilchmann, A.V. Jenkinson, G. Kanisch, G. Kis-Benedek, R. Kleinschmidt, V. Koukouliou, B. Kuhar, J. LaRosa, S.-H. Lee, G. LePetit, I. Levy-Palomo, L. Liong Wee Kwong, M. Llauradó, F.J. Maringer, M. Meyer, B. Michalik H. Michel, H. Nies, S. Nour, J.-S. Oh, B. Oregioni, J. Palomares, G. Pantelic, J. Pfitzner, R. Pilvio, L. Puskeiler, H. Satake, J. Schikowski, G. Vitorovic, D. Woodhead, E. Wyse, A new certificated reference material for radionuclides in Irish sea sediment (IAEA-385), Appl. Radiat. Isot. 66 (2008) 1711-1717.

[28] S. Röllin, H. Sahli, R. Holzer, M. Astner, M. Burger, Pu and Np analysis of soil and sediment samples with ICP-MS, Appl. Radiat. Isot. 67 (2009) 821-827.

[29] E. Hrnecek, R. Jakopič, A. Wallner, P. Steier, A combined method for the determination of the isotopic vector of plutonium isotopes in environmental samples, J. Radioanal. Nucl. Chem. 276 (2008) 789-793.

[30] Y. Guan, J. Mai, J. Xu, Z. Liu, Characteristic of Pu from urban wetland and lacustrine sediments in Suzhou Industrial Park, China, J. Environ. Radioact. 213 (2020) 106134, https://doi.org/10.1016/j.jenvrad.2019.106134.

[31] J.M. Kelley, L.A. Bond, T.M. Beasley, Global distribution of Pu isotopes and ${ }^{237} \mathrm{~Np}$, Sci. Total Environ. 237-238 (1999) 483-500. 